\title{
Scrotal Cystocele by Computed Tomography and Ultrasound
}

\author{
Cistocelo Escrotal por Ecografia e Tomografia \\ Computorizada
}

\author{
Diana PENHA 1 , Erique GUEDES PINTO $\rrbracket^{2}$, Ana COSTA ${ }^{1}$ \\ Acta Med Port 2017 Jan;30(1):81-81 - http://dx.doi.org/10.20344/amp.7513
}

Keywords: Cystocele/radiography; Cystocele/ultrasonography; Hernia, Inguinal/radiography; Hernia, Inguinal/ ultrasonography; Scrotum/radiography; Scrotum/ultrasonography; Tomography, X-Ray Computed

Palavras-chave: Cistocelo/radiografia; Cistocelo/ultrassonografia; Escroto/radiografia; Escroto/ ultrassonografia; Hérnia Inguinal/ radiografia; Hérnia Inguinal/ultrassonografia

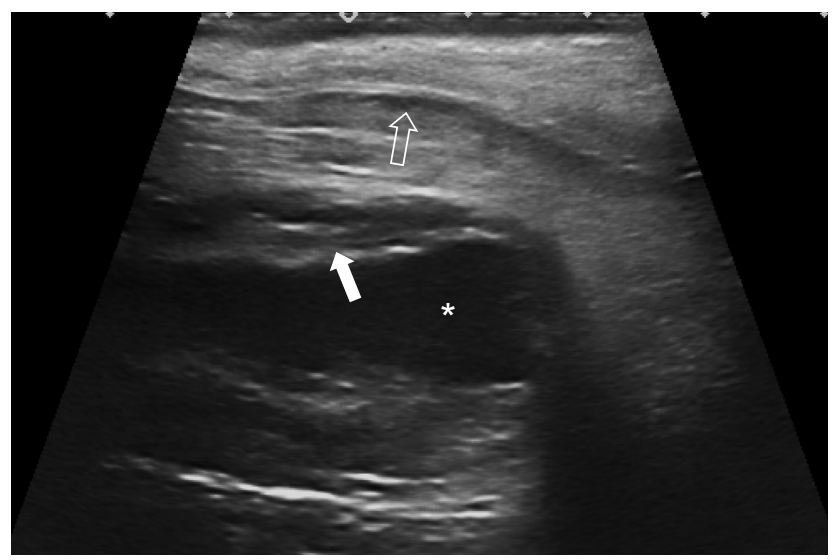

Figure 1 - Ultrasound scan in the left inguinal region shows a thick walled fluid filed tubular structure extending into the scrotum, which was mistaken for an inguinoscrotal hernia. The picture shows a tubular structure with thick wall (white arrow) containing fluid $\left({ }^{*}\right)$ representing the bladder herniation containing urine. The echogenic line (hollow arrows) is the inguinal canal lining separating the herniated fat content from the subcutaneous fat tissue of the scrotum, expressing oedematous changes.

A 44-year-old man is investigated for an intermittent left inguinal swelling and sent for ultrasound investigation which suggested an inguinal hernia. Because of discrepancy with the symptoms, a computed tomography (CT) is performed which reveals a scrotal cystocele.

Scrotal cystocele is the herniation of the urinary bladder through the scrotal sac. Besides being rare ${ }^{1}$, it can be easily mistaken for an inguinoscrotal hernia.

A clinical clue is the association between voiding and reduction of the scrotal cystocele.

Ultrasound scan may show no communication between the bladder and the scrotum (Fig. 1) or only a small beaklike indentation of the bladder. ${ }^{2-3}$ Even if a communication is

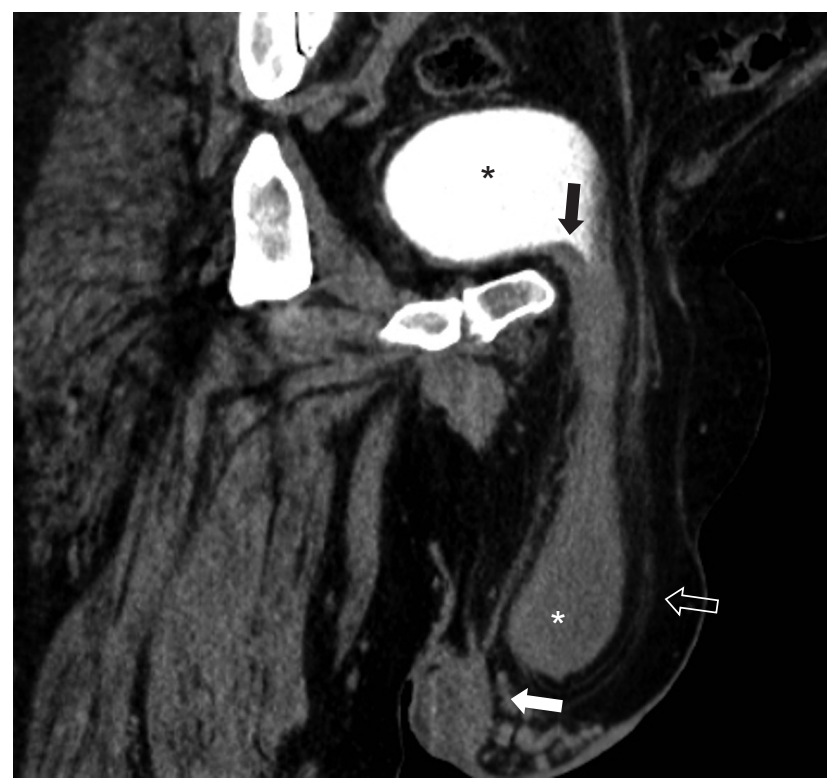

Figure 2 - Curvilinear multi-planar reformatting shows the fluid filed tubular structure extending from the urinary bladder $\left(^{*}\right)$ into the scrotal sac, with wall thickening (black arrow) and extending through the inguinal canal and displacing the testis (white arrow). The lining of the inguinal canal (hollow arrow) is seen separating the herniated fat tissue from the subcutaneous fat plane. The urine contained in the herniated bladder (white ${ }^{*}$ ) is not opacified because the wall thickening is obstructive to the passage of contrast.

seen, it may suggest an inguinoscrotal hernia instead. Lying supine for the ultrasound scan will allow for the fluid to drain back into the pelvis.

Careful review of the CT images (Fig. 2) will reveal the diagnosis and may reveal bladder wall thickening along the scrotal sac. ${ }^{4}$

\section{REFERENCES}

1. Dass K, Daloul R, Gupta P. Water under the bridge: a rare case of scrotal cystocele. BMJ Case Rep. 2013;bcr2013200239.

2. Hamidi Madani A, Mohammadi Nikouei H, Baghani Aval H, Enshaei A, Asadollahzade A, Esmaeili S. Scrotal herniation of bladder: a case report. Iran J Med Sci. 2013;38:62-4.

3. Weingardt JP, Russ PD, Ch'en IY, Robb LD, Pomerantz H. Scrotal cystocele detected by sonography. J Ultrasound Med. 1996;15:539-42.

4. Bacigalupo LE, Bertolotto M, Barbiera F, Pavlica P, Lagalla R, Mucelli RS, et-al. Imaging of urinary bladder hernias. AJR Am J Roentgenol. 2005;184:546-51.

1. Serviço de Radiologia. Hospital Prof. Dr. Fernando Fonseca. Amadora. Portugal.

2. Serviço de Radiologia. Lincoln County Hospital. United Lincolnshire Hospitals NHS Trust. Lincoln. Reino Unido.

$\square$ Autor correspondente: Erique Guedes Pinto. ericguedespinto@gmail.com

Recebido: 11 de fevereiro de 2016 - Aceite: 06 de junho de 2016 | Copyright @ Ordem dos Médicos 2017 